\title{
Report of the Annual Meeting
}

Rapports annuels de la Société historique du Canada

\section{American Concern over Canadian Railway Competition in the North-West, 1885-1890}

\section{Rosemary Lorna Savage}

Volume 21, numéro 1, 1942

URI : https://id.erudit.org/iderudit/300233ar

DOI : https://doi.org/10.7202/300233ar

Aller au sommaire du numéro

Éditeur(s)

The Canadian Historical Association/La Société historique du Canada

ISSN

0317-0594 (imprimé)

1712-9095 (numérique)

Découvrir la revue

Citer cet article

Savage, R. L. (1942). American Concern over Canadian Railway Competition in the North-West, 1885-1890. Report of the Annual Meeting / Rapports annuels de la Société historique du Canada, 21(1), 82-93. https://doi.org/10.7202/300233ar

All rights reserved @ The Canadian Historical Association/La Société historique du Canada, 1942
Ce document est protégé par la loi sur le droit d'auteur. L’utilisation des services d'Érudit (y compris la reproduction) est assujettie à sa politique d'utilisation que vous pouvez consulter en ligne.

https://apropos.erudit.org/fr/usagers/politique-dutilisation/ 


\title{
AMERICAN CONCERN OVER CANADIAN RAILWAY COMPETITION IN THE NORTH-WEST, 1885-1890
}

\author{
By Rosemary Lorna Savage \\ Columbia University
}

EARLY in the 1880's the railroads reached out from the eastern seaboard and entered the north-western region of the North American continent. True, the first transcontinental railroad had spanned the United States as early as 1869 , but this had followed the central route, through Missouri to California, and the north-western area remained more or less isolated, a sort of stepchild, rich in potentialities, but suffering from neglect. Then suddenly, within ten years, three transcontinental railways were built which had their terminals in the Pacific North-west. These were first, the Northern Pacific, which reached Puget Sound in 1883, second, the Canadian Pacific, which stretched across the Dominion of Canada in 1885, and the third, the Great Northern, which grew up in the territory between them, reaching completion in 1893.

Despite the political boundary of the 49 th parallel cutting across the prairies, this north-western area was essentially developed as a unit. This was partly owing to the environment, the semi-arid treeless plain being totally different from anything that the European settlers had experienced before. Dry farming, and the use of windmills and drilled wells, the importation of rapidly ripening spring wheat, adapted to the short growing season, and such inventions as the steel plow and the roller milling process, all had to be brought into use before the development of this area could be successfully established. Also the early advance into the mining areas of California and British Columbia had been an international movement, with California miners taking the predominant part in the whole development.

The history of canals and railroads in the East was such that it was natural for both Canadian and American railroad interests to expect to be able to carry traffic in either country and compete for trade across the border. There is evidence to show that during the period when the affairs of the Northern Pacific were dominated by the financial house of Jay Cooke and Company, from 1869 to 1873, there was considerable interest among the directors of this railroad in projects for the annexation of the British Northwest Territories. However, by the time the Northern Pacific was completed, the possibilities that such an annexation could be brought about had been considerably diminished. The purchase of the Hudson's Bay Company's lands by the Canadian government, the completion of Confederation of the British provinces, the adherence of British Columbia to that confederation, and the fact that the Canadian Pacific was under construction, meant that the scattered British possessions were coming to possess some internal cohesion, and were no longer solely dependent for communications and transportation with the rest of the world upon their neighbour to the south.

These developments did not meet with unmitigated approval in the United States, however. There had been no particular attempt in Canada to hide the fact that the building of the Canadian Pacific had political as well as economic motives, and the whole scheme was regarded with suspicion by the anti-British elements in Washington, who looked 
upon it as a scheme for enhancing British power upon the North American continent.

From these groups, therefore, there came a demand that the situation with regard to Canadian railroads should be reconsidered, with the new factors introduced by the building of the Canadian Pacific taken into consideration. The right of both countries to ship goods across the territory of the other in bond had been recognized in the Act of Congress of 1866 and the Treaty of Washington of 1871. By executive action this agreement had been extended to cover the western trade as well, without causing much comment. Those who opposed the Canadian railways wanted to rescind these privileges.

In 1889 an investigation was carried on by the Interstate Commerce Committee of the Senate on the subject of Canadian railroads operating in the United States. The issue which precipitated this investigation was the appearance of reports in the press that the Canadian Pacific had acquired the Minneapolis, Sault Ste. Marie and Atlantic Railway, and the Duluth, South Shore and Atlantic Railway. In the words of Senator Cullom the acquisition of these "Soo" lines gave to the Canadian Pacific a monopoly over the St. Mary's Bridge which would enable it to ignore and defeat the operation of the Interstate Commerce Act in letter and in spirit. ${ }^{1}$

More fundamental changes had occurred, however, which made such an investigation necessary. One was the passage of the Interstate Commerce Act in the United States in 1887, which placed the American lines under some form of restraint in their competition with each other and with Canadian railroads. In particular they had to abide by the long-and-short haul clause which prevented them from charging less for a long journey than they did for a shorter one, and the pooling of traffic by competing railroads was forbidden. At the same time the aggressive spirit shown by the Canadian Pacific in competing for American trade was increasingly evident.

The Interstate Commerce Committee was asked to

ascertain and report to the Senate whether any railroad lines located in the United States are owned, operated or controlled by the Grand Trunk Railway, the Canadian Pacific Railway Company or any other Canadian railroad corporation; whether commerce originating in the United States is diverted from American to Canadian lines of transportation, and if so, to what extent and by what means; . . . to inquire fully into the question of the regulation of the commerce carried on by railroad or water routes between the United States and the Dominion of Canada, and to report what legislation on the subject, if any, is necessary for the protection of the commercial interests of the United States or to promote the enforcement of the act to regulate commerce approved February $4,1887 .{ }^{2}$

In studying the influences which lay behind this senatorial investigation, some attention must be given to the relationships between these three north-western railroad lines. Serving the same territory as they did, inevitably they became rivals. Politically the two American lines,

119 Congressional Record, 50 Cong., 1 sess., p. 6769 (July 25, 1888).

${ }^{2}$ U.S. Senate Reports, 51 Cong., 1 sess., no. $847,1$. 
the Northern Pacific and the Great Northern, could be considered as uniting against their Canadian competitor. On the other hand, from a financial point of view, the Canadian Pacific and the Great Northern had closer ties in that they had both been originally built by the same group and financed by many of the same sources. In 1883, it was true, a break had come between the latter lines when James J. Hill resigned from the Board of Directors of the Canadian Pacific, and Stephen and Angus from the directorate of the St. Paul, Minneapolis and Manitoba, the forerunner of the Great Northern. This break was occasioned by the decision of the Canadian Pacific to build the section north of Lake Superior, which meant that the Canadian Pacific would be an independent system with its own eastern outlets, rather than a gigantic feeder for the St. Paul, Minneapolis and Manitoba. Hill gave a simple account of this decision in his testimony before the Senate Interstate Commerce Committee. "I sold out my interests in the Canadian Pacific. I saw a conflict was coming and I said 'We will part friends'."'3

In a letter to Hill, Stephen and Angus outline their views on the future of the two lines. "Neither of us has any intention of materially reducing our holdings in the stock, so long at least as the policy of the Company is not hostile to the Canadian Pacific Railway, for which we are more immediately responsible. We are of opinion that, while the two properties are and may continue to be entirely independent of each other, both have much to gain by the maintenance of an intimate and friendly alliance." They saw no reason why the two concerns should not work in harmony. The Canadian Pacific intended to push construction to the coast. "The traffic accruing to the St. Paul, Minneapolis and Manitoba railway from that source, and from the development of the Northwest territories cannot fail to be large, and to much more than compensate your company for any loss arising from the opening of the Thunder Bay and North Superior routes," they continued. "So far as we know, the entire railway traffic between the Canadian Northwest and the United States may be secured to the St. Paul, Minneapolis and Manitoba railway for a long period, while the Canadian Pacific Railway will strive to secure as much as possible of the business which naturally seeks its channel through Canadian territory."

However, it is interesting to note that the Senate Committee definitely suspected Hill of still being tied up with Canadian Pacific interests. At that time there seems to have been some doubt as to whether Hill really intended to build straight out to the coast or whether he would not rather make some agreement with the Canadian Pacific to give him an outlet to the coast, or even build himself through Canadian territory.

In any case the completely amicable relations suggested by Stephen and Angus do not seem to have worked out. The Canadian Pacific was not really ready to resign to American lines everything but "business naturally seeking its channel through Canadian territory." By making an agreement with the Pacific Steamship Lines it was able to compete with American transcontinental lines as far south as San Francisco. In 1888 the Canadian Pacific joined the Transcontinental Association, and received differentials on freight rates from San Francisco to points east of Chicago and also on passenger traffic to the Puget Sound area.

IIbid., Testimony, 168.

'J. G. Pyle, Life of James J. Hill (authorized) (New York, 1916), II, 324. 
Yet Van Horne definitely suspected that Hill had "exerted his influence at Washington to induce Congress to revoke the bonding privileges to Canadian railways" 6 and even employed an American lawyer from Detroit, Alonzo C. Raymond, to look after Canadian railroad interests in Washington.

At least three main groups can be discerned behind the agitation against Canadian railroads, which was to culminate in the Senate investigation. The first group demanded retaliatory legislation against Canada because of her treatment of American fishing vessels. Since the abrogation of the fisheries articles of the Treaty of Washington in 1885, American rights to fish in Canadian waters were regulated by the Convention of 1818. Seizure of American fishing vessels for alleged violations of the 1818 Convention stirred up resentment in the United States, particularly in New England, where the main objective was to prevent the free entry of Canadian fish into the American market. This outcry was fanned by the Republican group which was in control of the Senate, and which took a completely partisan attitude towards the foreign policy of Cleveland and Bayard. Baulked in its effort to negotiate by Republican recalcitrance and British refusal to bring strong pressure to bear upon Canada, the Administration decided to resort to the threat of retaliatory legislation. Two bills were introduced into Congress, one by Perry Belmont in the House of Representatives and the other by Senator Edmunds of Vermont in the Senate. ${ }^{6}$ The Belmont bill specifically authorized the President to forbid the entrance into the United States of Canadian merchandise and railroad rolling stock. The Edmunds bill did not mention the railroads specifically but empowered the President not only to prohibit the entrance of Canadian vessels into the United States but also to keep out fresh or salt fish or any other product of the Dominion, or goods coming from the Dominion to the United States. The Edmunds bill passed through Congress and received the presidential approval in March, 1887.

It was not brought into prominence again, however, until the refusal of the Senate to ratify the Fisheries Treaty, which was finally negotiated between the United States and Great Britain in the spring of 1888, made it necessary for the Administration to consider what further action it should take. As the terms of the rejection of the treaty made it obvious that any negotiations between the United States and Great Britain on the fisheries question were futile, it was suggested that Bayard should throw the issue squarely before the Senate by asking that the President should be empowered to carry out the retaliatory provisions of the Act of March 3, 1887. Such legislation was bound to be unpopular among the northern states, where the Canadian railways were of great importance to their prosperity, so that this suggestion placed the Senators from those states in an awkward position, particularly as congressional elections loomed ahead.

A second group can be differentiated which demanded that Canadian railroads should be kept out of the United States because of the belief that in this way Canada would be more inclined towards annexation to the United States. This philosophy was, of course, diametrically opposed 233.

'Walter Vaughan, The Life and Work of Sir William Van Horne (New York, 1920),

'House Resolution 10786, 49 Cong., 2 sess.; Senate bill 3173, 49 Cong., 2 sess. 
to the commercial union movement, which was also regarded as being at least tinged with annexationism. General James $H$. Wilson, who seems to have been the first to make charges against the Canadian railroads before Congress, was clearly of this school of thought. In a debate with Erastus Wiman before the Board of Trade of Wilmington, Delaware, in December, 1889, Wilson made it clear that he believed strongly in the manifest destiny of the United States to extend its sway all over the American continent. "It is as immutable and as constant as the law of gravitation-No policy on our part, or on the part of the Canadians, or even on the part of a federated British Empire, can abrogate or annul this law, and yet the question of policy is an important one to this generation, for policy may hasten or delay the fulfilment of our destiny, though it cannot defeat it."7 The policy which, in his estimation, should be followed by the United States would be to invite the Canadian provinces into the American union. "Should they fail to accept this generous offer they cannot regard it as at all unkind or unneighborly in us if instead of consenting to a Commercial or Customs Union, the United States at once repeal laws and abrogate the treaty under which the Transit Trade is conducted." 8 Among other specifications, Canadians are to give due respect to the "unimpeded operation of the law of our natural growth, with all that the law in its fullest sense can be construed to mean." General Wilson's views were backed up by Dana in the New York Sun.

Echoes of Wilson's philosophy can be seen in many of the discussions which came up before the Committee. For instance, when Chauncey Depew, the President of the New York Central, was being questioned, he declared that he was in favour of commercial union because he believed that "political union follows commercial union very rapidly."10 Senator Blair insisted, however, that the Canadian government had built the Canadian Pacific just because it did not want Canada to fall into the hands of the United States.

Another opponent of the Canadian railway lines who saw the menace of Canadian competition largely as a political threat was Joseph Nimmo, Junior, for many years the Chief Statistician of the Treasury Department. Nimmo waged a long and intensive campaign against the $\mathrm{Ca}$ nadian railroads. He warned the American people that the Canadian government had been transformed from a political organization into an aggressive transportation system. This was the guise which they must expect it to assume in any negotiations with the American people. "The Canadian aggression upon American interests is therefore a natural expression of the character of their government." 11 The United States is forced to consider "whether the United States or the British Empire is to hold the commercial supremacy on this continent." 12

Nimmo believed that the American government had made a great mistake in extending the transit privileges of the Act of 1866 and the

\footnotetext{
${ }^{7}$ Remarks of General James $H$. Wilson, in Joint Debale with Erastus Wiman, Esquire, before the Board of Trade and Citizens of Wilmington, Del, on "Our relations with Canada," Dec. $13,1889,13$.

Ibid., 26.

IIbid., 27.

${ }^{10}$ Senale Report, no. 847,51 Cong., 1 sess., Testimony, 82.

${ }^{11}$ Ibid., 652.

${ }^{12}$ Ibid, 654 .
} 
Treaty of Washington to the ports of the Pacific coast. The Treaty of Washington had been made fifteen years before the completion of the Canadian Pacific, he argued, and the growth of the transcontinental railroads had entirely changed the situation. None of the reciprocal advantages which existed in the East applied to the western transit trade. The absence of interjecting territory made such an arrangement unnecessary to secure the shortest route. Nor were there any natural advantages of water transportation on the Canadian side in the West. Victoria had no disability, like Quebec, of her ports being ice-bound all winter. The eastern transit trade tended to bring trade to American sea-ports, while the Canadian Pacific Railway with its British steamer line adjuncts, operated very strongly to turn American commerce from American seaports. This fact created great alarm on the Pacific coast and led the convention of commercial and industrial organizations of the section to appeal to Congress for protection against the aggressions of the Canadian and British governments. ${ }^{13}$ Nimmo's final indictment of the C.P.R., however, sprang from his suspicions of the political objectives which he believed it hoped to secure. In particular, the subsidized steamer lines to Asia threatened to ruin American steamer lines and to divert traffic to Canadian ports. In general he believed the plan for subsidized steamers to be part of a general scheme of "imperial confederation," and he dwelt darkly on the close identification of the Canadian Pacific with certain military objectives, particularly the formidable fortress and naval station at Esquimalt.

The third broad group which can be distinguished in the agitation against the Canadian railroads consisted of those railroad interests which dragged in the question of Canadian competition as an excuse for abandoning the unpopular long-and-short haul clause of the Interstate Commerce Act, and for securing the legalization of pooling. Raymond clearly thought that this was an important motive as far as the railroad magnates were concerned. "Concealed behind all the specious arguments of the American railway interests, lies, in my opinion, a preconcerted determination to have Congress legalize pooling, and leave the reasonableness of rates to the interstate commerce commission to determine. Should this be accomplished the regulative influence of Canadian lines in making rates reasonable would cease to be of value."14 Josiah White, a member of the New York Chamber of Commerce, summed this up when he said, "I do not think the complainants have proven their case, or that the remedies sought should be applied."15 The railroad magnates were "utilizing the question now under consideration for a reason why the anti-pooling section and the long-and-short haul clause should be repealed." 16

An interesting altercation developed between Senator Hiscock and A. C. Raymond as to the forces behind the investigation. Hiscock asserted that Raymond was "fighting phantoms" and that there was no disposition on the part of the American lines to try and cut off Canadian roads. He held that there was not the slightest railroad influence at the bottom of the investigation, which was simply prompted by a desire to perfect the interstate commerce legislation in regard to this aspect of the situation. ${ }^{17}$
${ }^{13}$ Ibid., 659 .
${ }^{14}$ Ibid, 16.
${ }^{15}$ Ibid., 302.
${ }^{10}$ Ibid., 303.
${ }^{17}$ Ibid., 566. 
Canadian as well as American railroad interests made their appearance before this Senate Committee. When Van Horne came before the Committee he tried to disabuse the minds of the American legislators of some of the objections to the Canadian Pacific which they were harbouring. In the first place, he tossed aside the argument that the Canadian Pacific was other than a profit-making organization. The main interest of the shareholders and directors of the Canadian Pacific was "to make the most money they can out of the Canadian Pacific Railway for their shareholders. They are not moved by sentiment or political considerations very much."18 Following this line of argument, he pointed out that the subsidies given to the Canadian Pacific were actually less, in proportion to what they had to do, than those granted to the Northern Pacific and the Union Pacific and Central Pacific. "The idea seems abroad," he went on to say, "and has been thoroughly circulated in the newspapers on this side of the line, that the Canadian Pacific is a sort of pampered pet of the Dominion Government, and that it is in receipt of favors every day. The Canadian Pacific Company gets no assistance from the Dominion government except to the extent of the ordinary compensation for carrying the mails just as the roads do here in this country, except that we do not get so much." 19 As for the subsidies to Pacific steamships given to the Canadian Pacific Company, "they have no relation whatever to any competition with United States lines, and there is no thought of such a thing in Canada. The relations between the Canadian Pacific Railway Company and the Dominion government are no closer than those between the Pennsylvania Railroad Company and the Government at Washington-not so close really. In fact, there has been a coolness between the Canadian Pacific Company and the Dominion Government for a number of years back."

Frequent allegations were made that the Canadian lines were increasing the proportion of American trade that they carried, and that this was the result of the giving of secret rebates. Much confusion existed as to the degree to which the Canadian lines were subject to the interstate commerce law. The Interstate Commerce Commission had realized the problem from the first, and had had no hesitation in applying the Act to Canadian lines in regard to business which in any way came within its jurisdiction. Both Joseph Hickson, the general manager of the Grand Trunk Railway, and Van Horne, strenuously denied that the Canadian lines were making any attempt to evade the operation of the Act. Nor could any actual evidence be uncovered to show that such was the case. Most of the suspicions were just about as vague as the following extract from the testimony of Mr. King, President of the New York, Lake Erie and Western Railway: "Of course we can not tell how they act up there, not nearly as well as we can tell how we act ourselves; but we know this, that they have abundant opportunities for doing things contrary to law without being punished." 20 Charles S. Smith, President of the Chamber of Commerce of New York City, said: "I know that the Canadian railroad officials claim that they observe the provisions of the interstate commerce law. It is denied on the part of our American friends. I know personally that the Canadian lines are getting a very much larger percentage of business from the New England 
states and Chicago than they received in former years, and $I$ think it is due to our exclusively American lines that they should have a fair investigation on that subject."21

The provisions of section 232 of the Canadian railway statute, specifically allowing discrimination between localities when it was necessary by reason of competition by water or railways to secure traffic, was cited as evidence that Canadian lines did not have to observe the longand-short haul principle with regard to their local traffic. Van Horne's evidence on this point is instructive. He submitted as evidence a letter from George Olds, the general traffic manager of the Canadian Pacific Railway Company, in which it was stated:

So far as States traffic is concerned, whether States to States traffic or traffic between Canada and the States, we have been governed by the interstate commerce law. We have not attempted to discriminate between individuals or localities; nor have we paid rebates or anything equivalent thereto in any shape or form; nor have we assisted our American connections in any way to evade the law.

We have been unable... to bring our domestic traffic strictly within the long and short haul principle; but I can safely assure you that both the letter and spirit of the interstate commerce law has been far better observed by the Canadian Pacific than by any of its competitors in the United States. The reports to the contrary originate with rival lines or interested parties and their purpose is obvious. ${ }^{22}$

Olds went on to discuss the provisions of the Canadian laws which prohibited pooling and discrimination between persons and localities, although there was no long-and-short haul clause, largely owing to the prevalence of water competition. "Our deviations from the long and short haul principle in this domestic traffic do not in the slightest degree affect our American competitors," he declared, although he admitted that the opening of the "Soo" lines might require changes in local tariffs. ${ }^{23}$

The Canadian lines could also argue that they had no more freedom than many of the American lines enjoyed in regard to their traffic located within one state. The difference in character of the local traffic enjoyed by American lines and the sparsely developed territories through which the Canadian Pacific ran was pointed out both by J. J. Hill and Alonzo C. Raymond. Hill thought that "if the Canadian roads were compelled to do business throughout the Dominion on the conditions that the Americans are compelled to do their business in America, that the Canadian roads, notwithstanding the liberal bonus, could not live."24 Raymond held that the advantage was all with the American lines in regard to local traffic despite the long-and-short haul clause. The local traffic, for instance, of the New York Central was so great that the system was beyond the influence of the Interstate Commerce Act. The Pennsylvania system and the Michigan Central were in much the same position. He also pointed out that the ruling of the Interstate Commerce Commission in the Buffalo rates case had shown a determination on the part of the Commission to construe the law strictly against Canadian lines. ${ }^{25}$

21 Ibid., 279

2Ibid., 254.
${ }^{29}$ Ibid., 255.

${ }^{24}$ Ibid., 183-4.
${ }^{25} I b i d .$, 500-1. 
It was suggested by Mr. Smith that the control which the Canadian Pacific had acquired over the Far Eastern trade must be the result of the giving of secret rebates. ${ }^{26}$ However, further discussion of the topic disclosed that the Canadian Pacific had advantages in the fact that the goods had to be handled only once, instead of twice, as would occur on American railroads, and that this was a great saving when goods were being shipped in bulk. The factor of subsidized shipping routes was also shown to be important.

The most effective arguments against stringent or coercive legislation against the Canadian railroads, however, came from Boards of Trade and representatives of industries and commerce in the New England and Middle Western towns. Many of these were dependent upon Canadian railroads and their connections for transportation or at least dependent upon Canadian lines to provide competition with the American lines and keep rates at a low competitive level. The most sweeping statements along this line came from Erastus Wiman, who claimed that

There has been no contribution to the Western States quite so advantageous as the construction of the Canadian railways. Next to the construction of the American railways and the provisions of nature in the waterways . . . these Canadian railroads have proved the most beneficial. I think the Canadian railways have contributed more to the facilities for the handling of products going east and the merchandise going west, at rates lower than ever before dreamed of, than any other enterprizes that have been inaugurated in this country. First, there is the directness of the route, and second the business has been done at rates so low that they never paid anything on the capital invested. ${ }^{27}$

Wiman believed that the continued prosperity of these roads was dependent on the retention of the bonding privilege. As far as the Canadian Pacific was concerned, if the new lines constructed from Sault Ste. Marie and Duluth were rendered valueless by the abolition of the bonding system, "not only the system of the Canadian Pacific but the whole northwestern railway system that has an outlet in the direction of Duluth and hence to Boston and the New England States would be paralyzed, to the great injury of the West and the East also.'23 Charles C. Bowen, a Detroit business man, argued that "if the British government has subsidized railroads in Canada, and thereby brought immeasurable advantages to us, it is our duty to foster this state of affairs. If it is desirable to have in mind the acquisition of Canada peacefully, we should cultivate close commercial relations. On the other hand, it may be urged that in so doing we strengthen the hands of a foreign people. True, we do; but if we add to our own strength by this process in a ratio of five to their one, which I think is our experience in the past, it is the only true course to pursue." 29 This supports Raymond's view of the matter. He pointed out that the strong defence of the Canadian railroads by the Chicago Board of Trade surprised the Senate Committee, in so far as the Canadian low rates had been instrumental in building up north-western towns like Minneapolis, St. Paul, and Duluth, to the detriment of

${ }^{26}$ Ibid., 280.

${ }^{27}$ Ibid., 190.
${ }^{28}$ Ibid., 191.

${ }^{29}$ Ibid., 522 . 
Chicago. The "Soo" lines in particular tended to divert trade from Chicago. ${ }^{30}$

Various suggestions were made for remedying the situation. Despite the absence of any concrete evidence that the Canadian railroads were not abiding by the interstate commerce law, many of the railroad men professed that they would be satisfied if they were sure that the Canadian railroads were governed by the interstate commerce law to the same extent that they were. Most of them recognized the essential difficulty that it was impossible for an American railroad commission to lay down regulations for local traffic that took place entirely in Canada. As long as Canadian railroads valued the privilege of operating in American territory, however, the threat could always be held over them that unless they complied with American regulations, their bonding privileges would be rescinded. Such action could be taken by both sides, however, and it is significant that one of Raymond's functions in Washington was, if necessary, to remind unduly belligerent legislators that if the agitation in Washington were successful, Canada was in a position to pass retaliatory measures. ${ }^{31}$ In general, it can be said that Canadian roads were anxious to comply with American regulations at least so far as their American trade was concerned, as they had a good deal to lose if they inflamed American opinion against them by arbitrary and discriminatory actions. The Committee took some cognizance of this argument in weighing the vague charges made against the Canadian railroads.

Many spoke in terms of making the Canadian railroads adopt the same legislation as the Americans had already accepted, without any opportunity to adapt it to special Canadian problems. However, those who had given most thought to the matter, were in favour of some kind of agreement with Canada according to which the railroad legislation of the two countries would be brought into line. Suggestions were also made in terms of a treaty, or diplomatic negotiations, perhaps the germ of the idea which was to lead the Senate in 1911 to send to Canada a proposed treaty for the setting up of an International Railroad Commission. No action has ever been taken on this agreement in Canada.

Perhaps J. J. Hill had some such international tribunal in mind when he said: "Those matters along our very long border will come up some day, and they will be very interesting subjects for international negotiation. There are some nice points in question. I do not know why there should be any great difficulty in settling them, but I think it would be well to have them settled.'32 To this the Chairman of the Committee, Senator Gorman, brusquely replied by suggesting that "as good a way as any to settle these questions would be by making Canada a part of the United States." 33

The question remained, however, as to whether rigid enforcement of the Interstate Commerce Act would really do the American railroads much good-particularly the transcontinental lines, which seem to have made the most determined attacks on Canadian railroads. Senator Blair came out squarely and asked Mr. Ledyard, the President of the Central Michigan Railroad, if it were not true that it was not of the

${ }^{80} \mathrm{~A}$. C. Raymond, Relalions between American and Canadian Railways, Address before Traffic convention held at Sault Ste. Marie, Mich., Aug. 28, 1889, 10.

"Vaughan, Life of Van Horne, 171.

${ }^{32}$ Senate Report, no. 847, 51 Cong., 1 sess., Testimony, 179.

33Ibid., 179. 
slightest consequence to American railroad men to apply the interstate commerce law in Canada, as the law then stood, and Ledyard agreed with him. Ledyard was in favour of the American railroad commission being enabled to regulate the rates charged by Canadian railroads in the United States, the theory being that the Canadian railroads were built with public money to a large extent and were not governed by the same considerations with regard to the necessity of making profits as the American lines. ${ }^{34}$ In fact, the whole discussion of the Committee tended to develop into a wide appraisal of the value of the Interstate Commerce Act, and many suggestions were made for the legalization of pooling and the repeal of the long-and-short haul clause, the allowance of special terms on exported goods, and the necessity for subsidies to American steamships to compete with the British subsidized lines.

The actual recommendations of the Committee were very mild, in comparison with the hostile tone adopted toward the Canadian railroads in the body of the report. The tone of the report had been more or less set by a whole-hearted adoption of Nimmo's extreme views about the political menace of the Canadian Pacific Railway and British imperial federation. The conclusions of the Committee were summed up in the words:

At no period in our history have the American people been called upon to consider a scheme of encroachment upon American commercial interests more injurious than the scheme by the Dominion of Canada in the construction of the Canadian Pacific Railway, the subsidizing of British steamer lines on the Pacific ocean in connection with such railway, and finally by an arrangement by the Canadian Pacific Railway company with an American steamship company by which goods are carried in bond between Port Moody and the sea-ports of Washington, Oregon, and California to and from the East on the Canadian Pacific railway, rendering certain the destruction of American steamer lines now engaged in our foreign commerce and the diversion of our Asiatic commerce from American seaports to the ports of British Columbia. ${ }^{35}$

The Committee made three recommendations, only one of which concerned the railroad problem. It read as follows: "The general proposition that Canadian railroads which compete with American railroads for traffic between different points of the United States should be subjected to the same requirements of law and of regulations in pursuance of law which apply or may hereafter apply to American railroads, is so clearly marked by principles of justice and equity that it must command the assent of every fair-minded person." 36 The Committee went on to mention the controversy then raging as to the wisdom of repealing the long-and-short haul clause of the Interstate Commerce Act. "Whatever conclusion the committee may reach hereafter on that question as the result of the investigation it seems, in the judgment of the committee, to be the duty of Congress to take such action as will give American railroads an even chance in competition

\footnotetext{
${ }^{34}$ Ibid., 272.

${ }^{35}$ Senate Report, no. 847, 51 Cong., 1 sess., 53.

${ }^{a}$ Ibid., 54.
} 
with the roads of Canada doing business in the United States." The Committee referred again to sections 226 and 232 of the Canadian statute for the regulation of traffic. These sections were regarded as encouraging the Canadian railroads to discriminate in favour of traffic secured in the United States.

The Committee therefore recommended that either a licence system should be established applicable to Canadian railroads doing business in the United States, or that some other plan, not injurious to the general trade and commerce of the country, be adopted which would secure to American railroads an equal chance in competition with Canadian railroads. "Such action in the judgement of the committee, is in the interest not only of American railroads, and especially of American transcontinental lines, but in the interest of American commerce and of the general prosperity of the American people." 37

The failure of the American Congress to take any decisive steps in regard to Canadian competition is an interesting analogy to the breakdown of the Canadian attempt to provide a monopoly and freedom from American competition to the Canadian Pacific. Just as the people of Manitoba rebelled at non-competitive rates, and secured the right to charter roads to the American border in 1888, the people of the North-west and the New Englanders demonstrated that their interests were so intermingled with Canadian transportation facilities that no arbitrary discrimination could be made against them without serious harm to American interests. In both cases the efforts of the railroad interests to secure a monopoly broke down in the face of popular discontent.

\section{DISCUSSION}

In reply to questions, Miss Savage said that she did not regard the extension of the Great Northern to Puget Sound or into southern British Columbia as a direct result of Hill's hostility to the C.P.R. Mr. Brebner suggested that the key to Hill's action was a passionate interest in efficiency. He had set himself the challenge of making a railway pay over the high prairie, and he built wherever he thought revenue could be gained.

${ }^{37}$ Ibid., 54-5. 